\title{
Village Financial System: How Do the Village Government Officials Understand the System?
}

\author{
YuliantiYulianti \\ Faculty of Economics, Semarang University, Semarang 50196, Indonesia, \\ E-mail: yulianti@usm.ac.id \\ Dyah N.A. Janie \\ Faculty of Economics, Semarang University, Semarang 50196, Indonesia, \\ E-mail: dyahjanie@usm.ac.id
}

Sudarman

Sekolah Tinggi Ilmu Ekonomi AKA semarang, Indonesia

E-mail: sudarman_aji@yahoo.com

Received: Jan. 17, 2019 Accepted: Mar. 17, 2019 Online published: Mar. 20, 2019

doi:10.5296/ijhrs.v9i1.14231ＵRL: https://doi.org/10.5296/ijhrs.v9i1.14231

\begin{abstract}
This research aims at analyzing the village government officials' understanding on the village financial system. This research is conducted by distributing questionnaires to 148 village government officials in nine districts in Central Java. The data are then quantitatively processed. Some village officials are randomly selected and then interviewed as the additional supporting data. The research results show that the village government officials have a relatively good understanding on the village financial system, yet there is no significant difference among the groups of government officials. However, there is an interesting issue due to the research results that the Head of the Village has the highest understanding when compared to all village government officials. In addition, the village government officials with accounting background have a higher understanding on the village financial system than those with no accounting background.
\end{abstract}

Keywords: village fund, village financial system, village government official 


\section{Introduction}

Even the different locations of villages in regency and municipality can lead to differences in terms of development distribution Suhardi (2017), (Chen \& Sumaryadi, 2017). The difference would be even more complicated when we consider the highly complex geographical condition that Indonesia has. With around 80,000 villages spread to about 20,000 islands in Indonesia, the possibility for evenly distributing the development gets even lesser (Sumaryadi, 2017), Jane (2017) \& Suhardi (2017). The kelurahan(hereinafter sub-district) areas are relatively more prosperous than village areas. However, the more prosperous state does not necessarily mean better condition, since the massive urbanization has resulted in more complex problems.

Indonesia government has been aware that they need to emphasize more on development in villages in the hope that these villages will be more advanced and urbanization would decrease (Pawiro, 2017). For this purpose Law No. 6 Year 2014 is issued and Village Fund is allocated to all countries in Indonesia (PP.60, 2014), (PP. No.6, 2014). Nevertheless, the Law enactment and fund grant also create new problems. The human resources that the village governments have are relatively limited from both quality and quantity perspectives. Village government officials are neither accustomed yet to hold fund in large amount nor familiarized in making accountability report in a standard form using Village Financial System (Siskeudes) (Pawiro, 2017).

Even the village government officials' understanding on Siskeudescannot be measured yet so far. The different infrastructure condition among islandsand the necessity to upload their accountability report online increase the difficulty to monitor the Village Fund use. It is highly likely that those areas close to government centers would have better human resources and infrastructures and facilities Suhardi (2017), (Chen \& Sumaryadi, 2017). Based on the background above, this research is intended to analyze the understanding of village government officials on Siskeudes.

\section{Literature Review}

The village financial management is performed by planning, budgeting, administering, reporting, assuming accountability, nurturing and monitoring the village finance as well as its reporting and supervising and evaluating. All these activities are parts of the effort to stimulate improvement to village government administration, village development implementation, village social advancement and village society empowerment (PP.60, 2014), (PP. No.6, 2014).

The steps mentioned above should be preventing from being interrupted to enable its optimal functioning. Hence, village government officials should uphold good government governance, which include participation, accountability, transparency in managing the village finance. Village government officials should invite Badan PemusyawaratanDesa (BPD) or Village Deliberation Agency such as village public figure, religious figure, representatives from women, representatives from farmers, representatives from poor ones. Also, the accountability and transparency of village financial management should not just done 
horizontally (between Village Head and BPD), rather it should also be done vertically (between Village Head and the village society, or Village Head's superintendent). All documents and reports related to village financial management should be accessible to the society without any discrimination to certain groups (Hamzah, 2015) \& PP.No.6 2014). The government of Indonesia through Ministry of Village, Isolated Regional Development, and Transmigration of the Republic of Indonesia in synergy with the Ministry of Finance of the Republic of Indonesia develop a Village Financial System (Siskeudes). This Siskeudesis expected to be able to deal with the problems in presenting their accountability report to the government by producting accurate information which is helpful in making decisions and showing some sort of accountability. In addition, the generated information is also expected to be of use for predicting the magnitude of resources needed (Pawiro, 2017).

The amount of fund disbursed to each village is relatively substantial than the fund possibly owned by them previously. It is expected that Siskeudescan help village government officials deliver their accountability report by minimizing any fraud by making Siskeudes operation easier to allow them to produce a Report of Village Budget implementation realization and Report of Village-Owned Property (Annually). Villages are given great chances to manage their own administration and to implement their development in order to improve the villagers' welfare and life quality. Therefore, villages should be able to apply accountability principles in its governance. Any activity and information related to village financial management should be accessible and monitored by other parties of authority and nothing should be hidden or concealed(Hamzah, 2015) \& PP.Np.6 tahun 2014), Pawiro, 2017)

\section{Methods}

This research uses the indicators generated from previous research (Pawiro, 2017). Questionnaire is distributed to 148 respondents in nine regencies in Central Java. And the village government officials completing the questionnaire include Village Head, village secretary (carik), financial staff and other relevant departments. Here is the list of statements used in this research (Pawiro, 2017):

1. Village Financial System (SISKEUDES) can deal with the problems found in delivering accountability report to the government.

2. Village Financial System (SISKEUDES) is readily accessible at any time when needed.

3. Village Financial System (SISKEUDES) produces accurate information.

4. Village Financial System (SISKEUDES) presents helpful information for making decisions and delivering accountability report.

5. Village Financial System (SISKEUDES) presents helpful information for predicting the magnitude of resources needed.

6. It presents village financial statements using terms which can be easily understood by the information users.

7. People can access village financial statements via internet (website). 
8. Government provides guidance and consultancy services to village governments in regard to village finance, starting from planning, executing, administering and accountability reporting.

9. BPKPlaunches a Village Financial Governance System as an embodiment of Village Financial Governance Quality Improvement.

10. The very existence of Village financial governance system can help village government officials to deliver their accountability reports by minimizing any fraud.

11. The operation of Village Financial System (SISKEUDES) is made fairly simple and easy to operate by village government officials.

12. The government applies village financial transparency and accountability principles starting from planning, execution, administration, reporting, accountability and monitoring.

13. Report of village government administration statement consists of report of Village budget execution realization and Village-Owned Property Report (Annually).

14. With the enactment of Law Number 6 Year 2014, villages are given great chances to manage their own government administration and to execute the development in order to improve the villagers' welfare and life quality. Therefore, villages should be able to apply accountability principle in their government administration.

15. Any activity and information related to village financial management should be accessible and monitored by other parties of authority and nothing should be hidden or concealed.

\section{Result and Discussion}

The responses and statements of questionnaire in this research have been tested using validity and reliability tests and the results show that they are valid and reliable. The Pearson correlation test results show that the item values range from 0.571 to 0.807 at a significance of 0.000 ( $\mathrm{sig}<0.05$ ). Meanwhile, the Cronbach's Alpha value is $92.6 \%$. 
Table 1. Respondents Composition

\begin{tabular}{lll}
\hline Characteristics & & Percentage \\
\hline Sex & Male & 85.4 \\
Total & Female & 14.6 \\
Position & Village Head & 100.0 \\
& Village secretary & 18.2 \\
& Financial staff & 17.5 \\
Total & Others & 51.0 \\
\hline Education & & 100.0 \\
& Elementary & 2.9 \\
& Junior High & 3.6 \\
& Senior High & 66.4 \\
& D3 & 3.6 \\
Total & S1 & 22.6 \\
\hline Accounting Background & Yes & 0.7 \\
& No & 100.0 \\
Total & & 78.7 \\
\hline Age & $<21$ & 21.3 \\
& $21-30$ & 100.0 \\
& $31-40$ & 0.9 \\
& $41-50$ & 11.3 \\
Total & $>50$ & 21.7 \\
\hline
\end{tabular}

As can be seen above, most of village government official respondents are male and graduated from Senior High School or higher, with adequate accounting background and younger than 50 years old. These match the characteristics of most village officials in Central Java.

Table 2. Descriptive Statistics

\begin{tabular}{lcccc}
\hline Respondent & \multirow{2}{*}{$\begin{array}{c}\text { Mean } \\
\text { Position }\end{array}$} & $\begin{array}{c}\text { Standard } \\
\text { deviation }\end{array}$ & \multicolumn{2}{c}{ Empirical Range } \\
\cline { 4 - 5 } Village Head & 4.06 & 0.53 & 2.87 & Minimal \\
Village secreatry & 3.98 & 0.59 & 1.80 & 4.73 \\
Financial staff & 3.96 & 0.47 & 3.07 & 4.87 \\
Others & 3.80 & 0.68 & 1.80 & 4.87 \\
\hline Total & 3.90 & 0.61 & 1.80 & 4.93 \\
\hline
\end{tabular}

The descriptive statistics show that at 1-5 range, the village official respondents have relatively good understanding on Siskeudes. Village Headshave the best understanding than other village government officials. Meanwhile, village secretary and financial staff have relatively equal understanding, yet financial staff has better uniformity in terms of their understanding than village secretary. This is highly possible since village officials have relatively high educational levels, i.e. Senior High School to bachelor. Most village government officials have actually had adequate accounting knowledge. The respondents think that this accounting knowledge is extremely important. From many mean difference test 
results, no (significant) difference is found between the two groups of respondent (those with accounting and non-accounting background), yet their understanding on accounting has significant association with their understanding on Siskeudes.

Meanwhile, from the interview with several respondents, a summary of obstacles identified in the implementation of Siskeudesin the field can be made, including:

1. Lack of human resources, in terms of both their quality and quantity.

2. Frequently changing regulations and their unevenly-distributed dissemination.

3. Technical obstacles related to the implementation of Siskeudes application, such as:

a. When the realized fund use is greater than APBDesit cannot be included into Usage realization, unless an the budget has been amended;

b. The huge number of report outputs which should be presented; and

c. Unavailability of adequate internet connection, even some villages are not connected to the internet.

The village government official respondentsalso hope that:

1. The distribution of Village Fund can be made sooner.

2. The Siskeudesapplication will be improved to make it easier to operate and be understood.

3. The quantity and quality of human resources could be improved through more intensive assistance and training and it can be extended to include not just village government officials but also other relevant village institutions.

4. Training and practice on accounting and financial affairs along with their softwares could be held.

\section{Conclusion}

The research results show that the village government officials have a relatively good understanding on the village financial system, yet there is no significant difference among the groups of government officials. However, there is an interesting issue due to the research results that the Head of the Village has the highest understanding when compared to all village government officials. In addition, the village government officials with accounting background have a higher understanding on the village financial system than those with no accounting background.

For an accountable village financial governance, the commitment from village government officials is needed. Technical guidance is still highly needed to improve the village government officials' competence. The central/province/regency governments also need to support by improving the supporting facilities and infrastructures to make them adequate. Siskeudesapplication also need to constantly be updated to make it even simpler in its operation, easily understood, yet capable of producing a complete report. It is also important 
to make the nurturing and assistance from many relevant parties more effective.

This research has some weaknesses, such as: the indicators used in this research are still new, hence further testing is needed for them. Of all villages in Central Java, only a few of them are willing to participate. Most of them are afraid of being respondents. Thus, this research's results cannot be generalized. In the future, research on the same topic can expand its scope.

\section{Acknowledgment}

The researchers would like to extend their gratitude to the Ministry of Research, Technology and Higher Education of the Republic of Indonesia for the funding the researchers are provided with that this research can be completed.

The researchers would also like to thank Institute of Indonesia Chartered Accountants and the Government of Central Java Province who have been highly supportive towards the execution of this research.

\section{References}

Chen, S. (2011). A Comparative Study of Village and Township: A Governance across the Taiwan Strait, Journal of Chinese Political Science, 16, 453-454.

Hamzah, A. (2015). Tata Kelola Pemerintahan Desa: Menuju Desa Mandiri, Sejahtera dan Partisipatoris, 1 ed., Surabaya, Jawa Timur: Penerbit Pustaka, 2015. [ Village Governance Management: for Independent, Prosperous, and Participative Village]

Pawiro, Y., \& Janie, D. N. A. (2017). The Indicators of Village Administrative Officer's Understanding of Siskeudes: A Literature Study, Economics and Business Solutions Journal, 1(1), 81-90.

Pemerintah, P. (2014). PP No. 43 Tahun 2014 Tentang Peraturan Pelaksanaan UU No. 6 Tahun 2014 Tentang Desa, Pemerintah Pusat RI, Jakarta, 2014. [Central Government of The Republic of Indonesia, Government Regulation No. 43 Year 2014 on Implementation Regulation of Law No2014 o Village, Central Government of the Republic of Indonesia, Jakarta, 2014]

Pemerintah, P. (2014). RI, PP No. 60 Tahun 2014 Tentang Dana Desa yang Bersumber dari APBN," Pemerintah Pusat RI, Jakarta, 2014. [Central Government of The Republic of Indonesia, Government Regulation No. 60 Year 2014 on village Funds Derived From The Central Government of The Republic of Indonesia, Jakarta, 2014]

Pemerintah, P. (2014). RI, UU No. 6 Tahun 2014 Tentang Desa, Pemerintah Pusat RI, Jakarta, 2014. [Central Government of the Republic of Indonesia No.6 Year 2014 on Village, Central Government of the Republic of Indonesia, Jakarta, 2014]

Suhardi, I. (2017). Interviewee, Pengendali Teknis Bidang APD Perwakilan BPKP Jateng. [Interview]. 11 November 2017. [ The Technical Control in the Field of APD of Central Java BPKP Representative]

Sumariyadi, I. (2017). Ketua Paguyuban Kepala Desa Kabupaten Semarang. [Interview]. 11 November 2017. [ Association Head of Village Heads in Semarang Regency] 


\section{Copyright Disclaimer}

Copyright for this article is retained by the author(s), with first publication rights granted to the journal.

This is an open-access article distributed under the terms and conditions of the Creative Commons Attribution license (http://creativecommons.org/licenses/by/4.0/). 